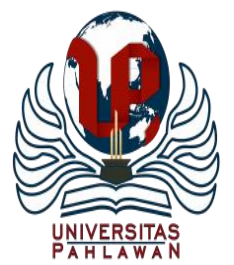

Edukatif : Jurnal Ilmu Pendidikan Volume 3 Nomor 4 Tahun 2021 Halm 1676 - 1682

EDUKATIF: JURNAL ILMU PENDIDIKAN

Research \& Learning in Education

https://edukatif.org/index.php/edukatif/index

\title{
Penerapan Model Pembelajaran Student Team Achievement Division untuk Meningkatkan Aktivitas Belajar Siswa Sekolah Dasar
}

\author{
Mahaishis Kusuma $^{1 凶}$, Muhammad Abduh ${ }^{2}$ \\ Universitas Muhammadiyah Surakarta, Indonesia ${ }^{1}$ \\ Universitas Muhammadiyah Surakarta, Indonesia ${ }^{2}$ \\ E-mail : $\underline{\text { mahaishis@gmail.com }}{ }^{1}, \underline{\text { ma123@ums.ac.id }}{ }^{2}$
}

\begin{abstract}
Abstrak
Penelitian ini bertujuan untuk meningkatkan aktivitas belajar siswa kelas 4 SD Negeri 03 Majalangu menggunakan model pembelajaran Student Team Achievement Division. Jenis penelitian ini adalah penelitian Tindakan kelas (PTK) yang terdiri dari dua siklus penelitian. Setiap siklus dilaksanakan dalam dua pertemuan dengan empat tahap kegiatan yaitu, perencanaan, tindakan, observasi, dan refleksi. Teknik pengumpulan data menggunakan observasi dan dokumentasi. Hasil penelitian menyatakan bahwa Student Team Achievement Division dapat meningkatkan aktivitas belajar siswa kelas 4 SD Negeri 03 Majalangu. Hal ini dibuktikan dengan data yang ditemukan pada siklus 1 terdapat 7 siswa yang masuk dalam kategori cukup atau 24\% dari seluruh siswa, terdapat 22 siswa yang termasuk dalam kategori baik atau $76 \%$ dari seluruh siswa. Pada siklus 2 terdapat 5 siswa yang masuk dalam kategori sedang atau 17\% dari seluruh siswa, ada 23 siswa yang masuk dalam kategori baik atau $79 \%$ dari seluruh siswa, dan ada 1 siswa yang masuk dalam kategori sangat baik atau sebesar 3\% dari seluruh siswa.
\end{abstract}

Kata Kunci: Student Team Achievement Division, aktivitas belajar.

\section{Abstract}

This research aims to improve the learning activities of $4^{\text {th }}$ grade students at 03 Majalangu Elementary School using Student Team Achievement Division. This type of research is a class action study consisting of two research cycles. Each cycle was held in two meetings with four stages of activities (planning, action, observation, and reflection). The research subjects were the forth grade students of 03 Majalangu Elementary School. The data collection techniques using observation and documentation. The results stated that Student Team Achievement Division can improve the learning activities of $4^{\text {th }}$ grade students at 03 Majalangu Elementary School. This is evidenced by the data found in first cycle there are 7 students in sufficient category or 24\%, there are 22 students students in good category or $76 \%$. In second cycle there were 5 students students in moderate category moderate or 17\%, there are 23 students in good category or $79 \%$, and there is 1 student in excellent category or $3 \%$.

Keywords: Student Team Achievement Division, learning activities.

Copyright (c) 2021 Mahaishis Kusuma, Muhammad Abduh

$\triangle$ Corresponding author

Email : mahaishis@gmail.com

DOI : https://doi.org/10.31004/edukatif.v3i4.653

ISSN 2656-8063 (Media Cetak)

ISSN 2656-8071 (Media Online) 
1677 Penerapan Model Pembelajaran Student Team Achievement Division untuk Meningkatkan Aktivitas Belajar Siswa Sekolah Dasar-Mahaishis Kusuma, Muhammad Abduh

DOI: https://doi.org/10.31004/edukatif.v3i4.653

\section{PENDAHULUAN}

Kurikulum 2013 (Kurtilas) muncul dimaksudkan agar guru menjadi lebih aktif, kreatif, dan inovatif dalam mengajar. Akan tetapi guru menyampaikan materi dengan menggunakan metode ceramah dan mengharapkan siswanya duduk, diam, dengar, catat, dan hafal. Hal tersebut dapat ditemui pada kegiatan pembelajaran yang ada di kelas IV SD N 03 Majalangu. Pernyataan tersebut diperkuat dengan hasil observasi dan wawancara yang telah dilakukan oleh peneliti. Berdasarkan hasil observasi yang dilakukan peneliti pada muatan pelajaran IPA, siswa pasif dalam mengikuti kegiatan pembelajaran dan siswa mendapatkan nilai rendah dari hasil tes yang diberikan oleh guru saat akhir pembelajaran. Kemudian peneliti melakukan wawancara kepada guru untuk mendalami masalah yang ditemukan pada saat observasi. Dari hasil wawancara diketahui bahwa guru kurang memahami macam-macam model pembelajaran yang dapat membuat siswa aktif saat mengikuti kegiatan pembelajaran.

Ada beberapa solusi yang dapat dilakukan untuk mengatasi masalah tersebut, pada penelitian ini peneliti mencoba menerapkan Student Team Achievement Division (STAD) dalam pembelajaran di kelas IV tema 6 muatan pelajaran IPA untuk menekankan aktivitas siswa di dalam pembelajaran. Peneliti memilih menerapkan STAD karena model pembelajaran STAD merupakan pendekatan Cooperative Learning yang menekankan pada aktivitas dan interaksi di antara siswa untuk saling memotivasi dan saling membantu dalam menguasai materi pelajaran guna mencapai prestasi yang maksimal (Wijaya \& Arismunandar, 2018:175). Hampir sama dengan pendapat tadi, Student Teams Achievement Division (STAD) adalah metode atau pendekatan dalam pembelajaran kooperatif yang sederhana dan baik untuk guru yang baru mulai menggunakan pendekatan kooperatif dalam kelas (Kristin, 2016:75). Pada penelitian yang dilakukan oleh Sumilat dan Matutu (2021:869) ditemukan bahwa STAD dapat meningkatkan motivasi belajar siswa sehingga bersinergi pada peningkatan aktivitas siswa, selanjutnya menumbuhkan rasa ingin tahu dan rasa percaya diri serta kemauan berdiskusi dan bekerja sama yang secara tidak langsung telah berbagi pengetahuan diantara sesama siswa saat proses diskusi dan tanya jawab. STAD juga merupakan suatu metode pembelajaran kooperatif yang efektif. Hal tersebut juga senada dengan pendapat Susanti (2020) bahwa STAD atau Tim Siswa Kelompok merupakan jenis pembelajaran kooperatif yang paling sederhana. Selain itu, tujuan penggunaan metode pembelajaran kooperatif dalam kegiatan mengajar adalah agar siswa berani mengungkapkan pendapat, gagasan dan sikap saling menghargai dalam kelompok (Mujazi, 2020:450). Jadi, siswa dapat belajar untuk berkomunikasi dengan anggota kelompoknya masing-masing saat kegiatan pembelajaran menggunakan model STAD. Dalam melakukan komunikasi dengan kelompoknya tersebut, siswa dapat belajar mengemukakan pendapat, menghargai perbedaan, dan menumbuhkan rasa ingin tahu.

Penelitian ini bertujuan untuk meningkatkan aktivitas belajar siswa pada tema 6 muatan pelajaran IPA melalui penerapan STAD pada siswa SD N 03 Majalangu kelas IV. Setelah dilakukan penelitian ini diharapkan siswa lebih mudah memahami materi, mendapatkan pengalaman bermakna, dan aktivitas belajarnya meningkat. Hasil penelitian terdahulu yang mendukung pemilihan pembelajaran STAD untuk meningkatkan aktivitas belajar siswa adalah penelitian oleh Darsana (2019), Afandi (2019), Mujazi (2020), Hewen dkk. (2020), Marsixtin (2019), Y. Susanti dkk. (2017). Penelitian-penelitian terdahulu tersebut menunjukkan bahwa model pembelajaran STAD dapat meningkatkan aktivitas belajar siswa.

\section{METODE PENELITIAN}

Jenis penelitian yang digunakan adalah penelitian tindakan kelas (PTK). Penelitian ini dilaksanakan di kelas IV SD Negeri 03 Majalangu yang beralamat di Jalan Raya Majalangu Timur, Desa Majalangu, Kecamatan Watukumpul, Kabupaten Pemalang, Provinsi Jawa Tengah. SD Negeri 03 Majalangu merupakan sekolah yang berada dalam naungan Dinas Pendidikan Kabupaten Pemalang. Prasiklus penelitian 
1678 Penerapan Model Pembelajaran Student Team Achievement Division untuk Meningkatkan Aktivitas Belajar Siswa Sekolah Dasar - Mahaishis Kusuma, Muhammad Abduh

DOI: https://doi.org/10.31004/edukatif.v3i4.653

dilaksanakan pada tanggal 25 Januari 2021, siklus 1 dilaksanakan pada tanggal 30 Januari 2021 dan 3 Februari 2021, dan siklus 2 dilaksanakan pada tanggal 8 Februari 2021 dan 22 Februari 2021.

Sasaran penelitian ini adalah meningkatnya aktivitas belajar siswa kelas IV SD Negeri 03 Majalangu. Subjek penelitian ini adalah siswa kelas IV SD Negeri 03 Majalangu dengan jumlah siswa sebanyak 29 anak. Terdiri dari laki-laki 15 anak dan perempuan 14 anak. Asal siswa dari desa di Kelurahan Majalangu dan sekitarnya. Berasal dari keluarga yang memiliki latar belakang pendidikan yang berbeda.

Penelitian ini dilakukan melalui empat langkah sesuai dengan pendapat Suryadi dan Berdiati (2018) yaitu perencanaan (planning), tindakan (acting), pengamatan (observing), dan refleksi (reflecting). Empat langkah tersebut merupakan sebuah siklus, pada penelitian ini dilakukan dua kali siklus dengan dua kegiatan pembelajaran. Jenis data yang digunakan dalam penelitian ini adalah data kuantitatif dan data kualitatif. Data kuantitatif dalam penelitian ini berupa aktivitas belajar siswa yaitu skor aktivitas belajar siswa pada siklus 1 dan siklus 2. Data kualitatif dalam penelitian ini berupa informasi berbentuk kalimat yang memberi gambaran tentang aktivitas siswa. Data tersebut berupa hasil pengamatan terhadap aktivitas belajar siswa dengan menggunakan lembar pengamatan pada siklus 1 dan sikus 2 . Sumber data berupa catatan lapangan berasal dari catatan selama proses pembelajaran berupa data aktivitas siswa, aktivitas guru dalam muatan pelajaran IPA. Tema 6. Penelitian ini menggunakan teknik pengumpulan data yaitu observasi. Observasi dalam penelitian ini dilaksanakan dengan mengamati aktivitas siswa dan guru dalam proses pembelajaran. Tujuan penggunaan teknik observasi pada penelitian ini adalah untuk mengetahui sejauh mana tindakan penerapan model pembelajaran STAD dan mengetahui bagaimana aktivitas guru dan siswa selama proses pembelajaran berlangsung. Data observasi yang telah diperoleh dianalisis secara deskriptif kualitatif yaitu peneliti mendeskripsikan hasil pengamatan dalam bentuk kalimat-kalimat untuk memberikan gambaran yang jelas tentang penerapan model pembelajaran STAD untuk meningkatkan hasil belajar dan aktivitas siswa pada tema 6 muatan pelajaran IPA.

\section{HASIL DAN PEMBAHASAN PENELITIAN}

Hasil-hasil yang didapatkan peneliti mulai dari silklus 1 dengan penerpan model pembelajaran STAD hingga akhir penelitian pada siklus 2 dirangkum dalam sebuah tabel sebagaimana berikut.

Tabel 1. Hasil Pengamatan Aktivitas Belajar Siswa

\begin{tabular}{cccccc}
\hline \multirow{2}{*}{ Skor } & \multirow{2}{*}{ Kategori } & \multicolumn{2}{c}{ Jumlah } & \multicolumn{2}{c}{ Persentase } \\
\cline { 3 - 6 } & & Siklus 1 & Siklus 2 & Siklus 1 & Siklus 2 \\
\hline $28-22$ & Sangat Baik & - & 1 & $0 \%$ & $3 \%$ \\
$21-15$ & Baik & 22 & 23 & $76 \%$ & $79 \%$ \\
$14-8$ & Cukup & 7 & 5 & $24 \%$ & $17 \%$ \\
$7-0$ & Kurang & - & - & $0 \%$ & $0 \%$ \\
\hline
\end{tabular}

Untuk lebih jelasnya, peneliti membuat diagram batang hasil rekapitulasi data observasi aktivitas belajar siswa di bawah ini. 
1679 Penerapan Model Pembelajaran Student Team Achievement Division untuk Meningkatkan Aktivitas Belajar Siswa Sekolah Dasar - Mahaishis Kusuma, Muhammad Abduh

DOI: https://doi.org/10.31004/edukatif.v3i4.653

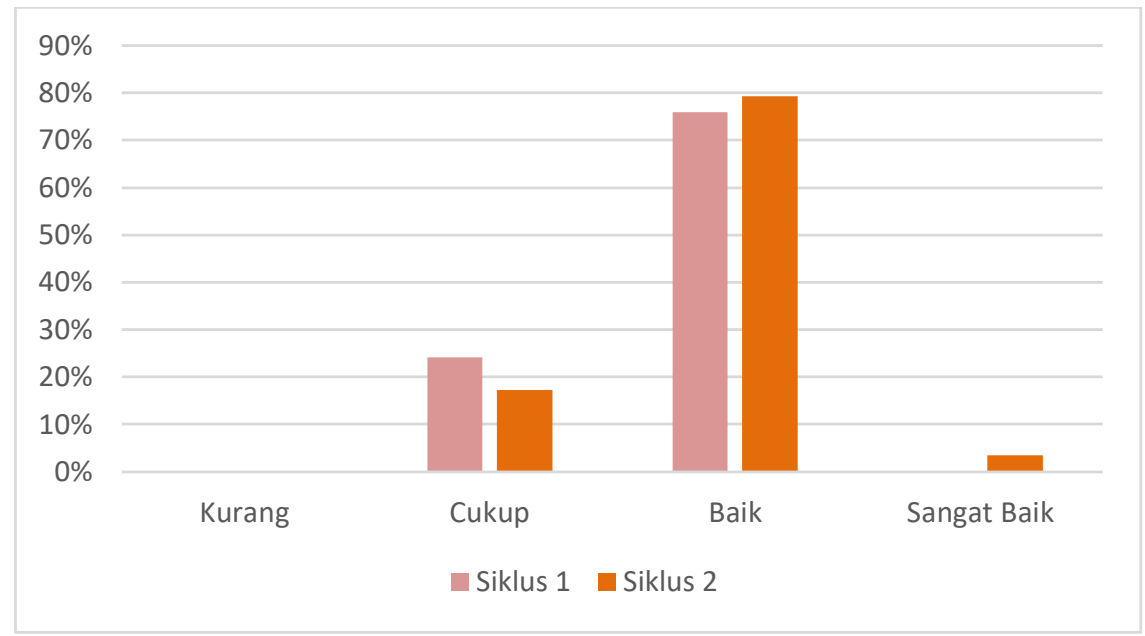

Gambar 1: Diagram Hasil Observasi Aktivitas Belajar Siswa

Pada tabel dan diagram di atas dapat diketahui bahwa ada peningkatan pada siswa yang memiliki aktivitas belajar kategori baik dan sangat baik di setiap siklus. Pada siklus 1 ada 7 siswa yang termasuk dalam kategori cukup atau sebesar 24\%, ada 22 siswa yang termasuk ke dalam kategori baik atau sebesar $76 \%$. Pada siklus 2 ada 5 siswa yang termasuk ke dalam kategori cukup atau sebesar 17\%, ada 23 siswa yang termasuk ke dalam kategori baik atau sebesar 79\%, dan ada 1 siswa yang termasuk ke dalam kategori sangat baik atau sebesar 3\%. Berdasarkan data tersebut, peneliti mengambil kesimpulan bahwa ada peningkatan aktivitas belajar siswa pada pembelajaran tema 6 muatan pelajaran IPA kelas IV di SD N 03 Majalangu menggunakan model pembelajaran kooperatif tipe STAD.

Hasil observasi yang dilakukan oleh peneliti akan didukung oleh temuan per indikator. Peneliti menggunakan 7 di antara 10 indikator berdasarkan pendapat Dierich (Sardiman, 2012) karena disesuaikan dengan karakteristik siswa. Berikut ini adalah data hasil observasi per indikator.

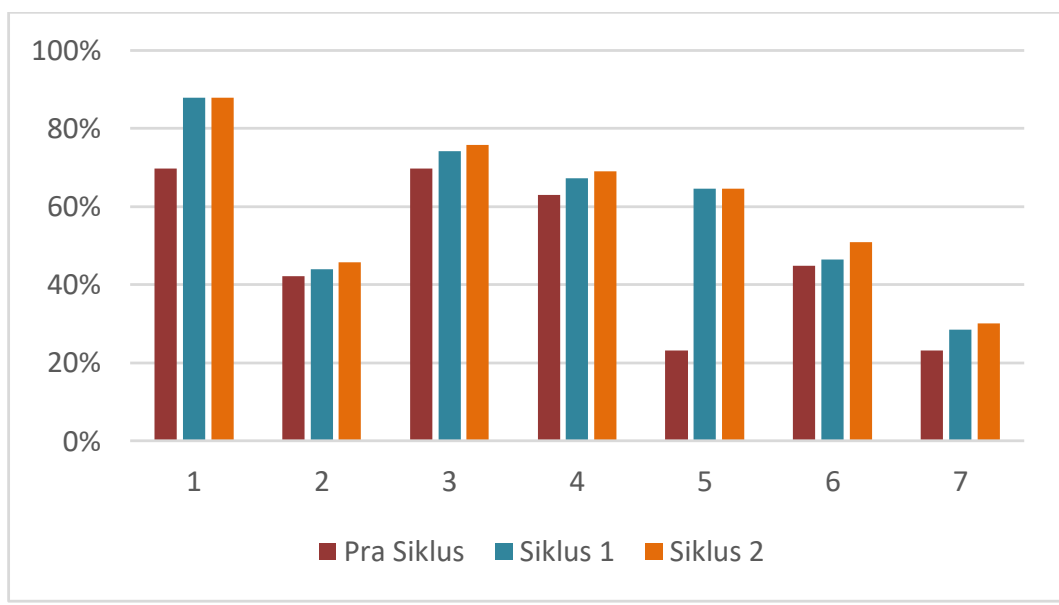

Gambar 2: Diagram Hasil Observasi Per Indikator

Terjadi peningkatan pada indikator 1 yaitu mempersiapkan diri dalam pembelajaran (mental activities). Diketahui pada pra siklus jumlah skor siswa sebesar 81, meningkat menjadi 102 pada siklus 1 dan siklus 2 . Terjadi peningkatan sebanyak 21 poin atau sebesar $25,9 \%$ dari pra siklus. Dari data hasil observasi dapat, setelah menerapkan model pembelajaran kooperatif tipe STAD, siswa lebih terdorong untuk mempersiapkan diri dalam pembelajaran.

Berdasarkan data observasi, indikator 2 yaitu menanggapi apersepsi (emosional activities) terjadi peningkatan dari pra siklus jumlah skor siswa sebanyak 49, menjadi 51 pada siklus 1 dan meningkat menjadi 
1680 Penerapan Model Pembelajaran Student Team Achievement Division untuk Meningkatkan Aktivitas Belajar Siswa Sekolah Dasar-Mahaishis Kusuma, Muhammad Abduh

DOI: https://doi.org/10.31004/edukatif.v3i4.653

53 pada siklus 2 . Terjadi peningkatan sebanyak 2 poin atau sebesar $4 \%$ dari pra siklus ke siklus 1 , sebanyak 2 poin atau sebesar 3,9\% dari siklus 1 ke siklus 2. Jadi, dari pra siklus sampai ke siklus 2, jumlah skor siswa meningkat sebesar 8\%. Aktivitas memberi tanggapan apersepsi meningkat meskipun tidak terlalu signifikan.

Pada indikator 3 yaitu memperhatikan penjelasan guru terjadi peningkatan. Saat pra siklus jumlah skor siswa sebanyak 81 meningkat 5 poin menjadi 86 pada siklus 1 dan mengalami peningkatan lagi sebanyak 2 poin pada siklus 2 menjadi 88. Dari pra siklus sampai siklus 2 terjadi peningkatan sebanyak 7 poin atau sebesar 8,6\%. Berdasarkan data tersebut, dapat diketahui bahwa menggunakan model pembelajaran kooperatif tipe STAD, siswa menjadi lebih antusias dalam memperhatikan penjelasan guru.

Terjadi peningkatan pada data observasi indikator 4 yaitu ketertiban dalam pembentukan kelompok. Peningkatan sebanyak lima poin atau sebesar $6,8 \%$ dari pra siklus dibandingkan dengan siklus 1 , kemudian pada siklus 1 dibandingkan siklus 2 terjadi peningkatan sebesar 2,5\% atau ada peningkatan skor sebanyak 2 poin. Peningkatan skor pada indikator ini sesuai dengan kelebihan pembelajaran STAD yang sesuai dengan salah satu pendapat menurut Priansa (2017:329) yaitu memberikan kesempatan kepada peserta didik untuk mengembangkan rasa menghargai, menghormati pribadi temannya, dan menghargai pendapat orang lain.

Berdasarkan data hasil observasi yang dapat dilihat di atas, pada indikator 5 yaitu mengerjakan latihan soal dengan kelompoknya (mental activities) diperoleh peningkatan yang cukup signifikan sebesar $177 \%$ dari skor 27 pada pra siklus, menjadi 75 pada siklus 1, lalu pada siklus 2 tidak terjadi peningkatan lagi pada indikator ini. Setelah menggunakan model pembelajarn STAD, aktivitas mengerjakan latihan soal dengan kelompoknya berjalan dengan efektif. Siswa mencoba menyelesaikan latihan soal dengan berdiskusi bersama kelompoknya untuk mendapatkan jawaban yang benar. Data tersebut juga sesuai dengan penelitian yang dilakukan oleh Fathimatuzzahrah (2020) yang menjelaskan bahwa pembelajaran menggunakan STAD dapat berinteraksi dan bekerjasama antar anggota kelompoknya yang heterogen sehingga siswa dapat saling memahami dan menerima perbedaan untuk menyelesaikan tugas kelompok. Pendapat tersebut juga sesuai dengan pendapat Prastya (2017:108) bahwa dalam setiap kelompok terdapat siswa yang memiliki kemampuan akademik lebih tinggi dan dapat dijadikan tutor bagi teman sekelompoknya sehingga ketika siswa mengalami kesulitan dalam memahami materi maka ia mempunyai kesempatan untuk menanyakan kepada temannya, dan temannya akan memberikan bantuan kepadanya dengan menjelasakan kepada anggotanya yang lain sampai mengerti.

Pada indikator 6 yaitu menjawab kuis kelompok terjadi peningkatan dari skor 52 pada pra siklus menjadi 54 pada siklus 1 dan menjadi 59 pada siklus 2. Pra siklus dibandingkan dengan siklus 2 ada peningkatan sebesar $13,4 \%$. Pada siklus 1 dan siklus 2 siswa terlihat lebih percaya diri dalam mengerjakan kuis yang diberikan oleh guru sebagai rasa tanggung jawab terhadap kelompoknya.

Terjadi peningkatan skor pada data observasi sebesar 22,2\% yaitu dari skor 27 pada pra siklus menjadi 33 pada siklus 1, kemudian meningkat lagi menjadi 35 pada siklus 2. Indikator 7 yaitu melakukan refleksi pembelajaran. Indikator 7 atau dalam melakukan refleksi pembelajaran, siswa masih mendapatkan skor yang rendah. Menurut hasil pengamatan yang telah dilakukan peneliti, hal tersebut disebabkan karena siswa belum terbiasa dan belum percaya diri untuk menyampaikan pertanyaan tentang apa yang masih belum mereka pahami.

Berdasarkan data di atas, dapat diketahui bahwa ada peningkatan pada setiap indikator pada setiap siklus. Hasil ini sesuai dengan penelitian yang dilakukan oleh Marsixtin (2019) di mana diperoleh data aktivitas proses belajar siswa dan data penilaian kerja kelompok memiliki skor yang sangat baik dari pertemuan pertama sampai pertemuan keempat, meningkat pada setiap siklusnya. Hasil penelitian ini juga sesuai dengan penelitian yang dilakukan oleh Hewen, Fayeldi dan Farida (2020) dijelaskan bahwa hasil penelitian menunjukan hasil aktivitas belajar siswa menggunakan model Student Team Achievement Division (STAD) pada siklus I sebesar 76\% dan pada siklus II sebesar 94\%. Berdasarkan penemuan peneliti, pembelajaran menggunakan STAD juga dapat melatih siswa berinteraksi dengan orang lain, juga 
1681 Penerapan Model Pembelajaran Student Team Achievement Division untuk Meningkatkan Aktivitas Belajar Siswa Sekolah Dasar-Mahaishis Kusuma, Muhammad Abduh

DOI: https://doi.org/10.31004/edukatif.v3i4.653

berkolaborasi untuk menyelesaikan masalah. Hal tersebut sesuai dengan penelitian yang telah dilakukan oleh Y. Susanti dkk. (2017). Hasil penelitian Y. Susanti menyimpulkan bahwa siswa dapat berlatih untuk bekerja sama atau berinteraksi dengan anggota kelompoknya, berlatih untuk mengemukakan pendapat, berlatih untuk memiliki sikap menghargai pendapat orang lain, dan dapat menumbuhkan rasa tanggung jawab dan kecakapan sosial mereka.

\section{KESIMPULAN}

Setelah dilakukan penelitian di kelas IV SD Negeri 03 Majalangu, dapat diperoleh data peningkatan aktivitas belajar siswa sebanyak $83 \%$ dari pra siklus sampai ke siklus 2 . Hal ini menunjukkan bahwa terjadi peningkatan aktivitas belajar pada setiap pertemuan. Model pembelajaran STAD dapat meningkatkan aktivitas belajar siswa dalam hal ini yaitu mampu membuat siswa lebih baik dalam mempersiapkan diri mengikuti pembelajaran, lebih antusias dalam menanggapi apersepsi, meningkatkan perhatian siswa pada penjelasan guru, meningkatkan ketertiban dalam pembentukan kelompok, dan mampu meningkatkan interaksi antar anggota kelompok. Dengan demikian dapat disimpulkan bahwa aktivitas belajar siswa di SD Negeri 03 Majalangu dapat ditingkatkan menggunakan model pembelajaran STAD.

\section{UCAPAN TERIMA KASIH}

Terima kasih kepada Bapak/Ibu Dosen Pendidikan Profesi Guru Universitas Muhammadiyah Surakarta dan teman-teman PPL serta Kepala Sekolah SD Negeri 03 Majalangu yang telah memberikan bimbingan dan arahannya. Semoga penelitian yang disusun ini dapat bermanfaat bagi semua pihak.

\section{DAFTAR PUSTAKA}

Afandi, M. (2019). Meningkatkan Aktivitas dan Hasil Belajar Pendidikan Kewarganegaraan Melalui Model Pembelajaran Kooperatif Tipe STAD di MI Muhammadiyah Tanjung Inten. Terampil: Jurnal Pendidikan dan Pembelajaran Dasar, 6(1), 1-13. https://doi.org/10.24042/terampil.v6i1.3875

Darsana. (2019). Upaya Meningkatkan Aktivitas Dan Hasil Belajar Penjaskes Peserta didik Kelas VI Di SD Negeri 22 Ampenan Melalui Penerapan Pendekatan Cooperative Learning (CL) Tipe STAD Semester Dua Tahun pelajaran 2018/2019. Jurnal Ilmu Sosail dan Pendidikan, 3(2). https://doi.org/http://dx.doi.org/10.36312/jisip.v3i2.721

Fathimatuzzahrah, A. (2020). Keefektifan Layanan Bimbingan Klasikal dengan Teknik STAD untuk Meningkatkan Kemampuan Kerjasama dalam Penyelesaian Studi Siswa. Jurnal Ilmu Pendidikan, 2(1), 1-7. https://doi.org/https://doi.org/10.31004/edukatif.v2i1.72

Hewen, S. L., Fayeldi, T., \& Farida, N. (2020). PENERAPAN MODEL PEMBELAJARAN KOOPERATIF TIPE STAD UNTUK MENINGKATKAN AKTIVITAS DAN PRESTASI BELAJAR SISWA. RAINSTEK: Jurnal Terapan Sains \& Teknologi, 2(3), 236-244. http://ejournal.unikama.ac.id/

Kristin, F. (2016). Efektivitas Model Pembelajaran Kooperatif Tipe Stad Ditinjau Dari Hasil Belajar Ips Siswa Kelas 4 Sd. Scholaria: Jurnal Pendidikan dan Kebudayaan, 6(2), 74. https://doi.org/10.24246/j.scholaria.2016.v6.i2.p74-79

Marsixtin. (2019). MENINGKATKAN PERILAKU AKTIVITAS DAN HASIL BELAJAR IPA MELALUI MODEL KOOPERATIF TIPE STAD SISWA KELAS VI SD NEGERI 003 PULAU PERMAI KECAMATAN TAMBANG KABUPATEN KAMPAR. Jurnal PAJAR (Pendidikan dan Pengajaran), 3(1), 133-142. https://pajar.ejournal.unri.ac.id/

Mujazi. (2020). PENGGUNAAN METODE PEMBELAJARAN KOOPERATIF TIPE STAD UNTUK 
1682 Penerapan Model Pembelajaran Student Team Achievement Division untuk Meningkatkan Aktivitas Belajar Siswa Sekolah Dasar - Mahaishis Kusuma, Muhammad Abduh

DOI: https://doi.org/10.31004/edukatif.v3i4.653

MENINGKATKAN AKTIVITAS DAN HASIL BELAJAR SISWA. Jurnal Indonesia Sosial Sains, 1(5), 448-457. https://doi.org/https://doi.org/10.36418/jiss.v1i5.76

Prastya, D. (2017). Peningkatan Hasil Belajar Ipa Melalui Penerapan Model Pembelajaran Cooperative Tipe Student Teams Achievement Division (Stad) Pada Siswa Kelas V Sekolah Dasar. EduHumaniora Jurnal Pendidikan Dasar Kampus Cibiru, 9(2), 99-108. https://doi.org/10.17509/eh.v9i2.7079

Priansa, D. J. (2017). Pengembangan Strategi \& Model Pembelajaran Inovatif, Kreatif, dan Prestatif dalam memahami peserta didik. CV. Pustaka Setia.

Sardiman, A. M. (2012). Interaksi dan Motivasi belajar Mengajar. PT. Raja Grafindo Persada.

Sumilat, J. M., \& Matutu, V. S. (2021). Model Pembelajaran Kooperatif Tipe STAD ( Student Teams Achievemen Divisions ) untuk Meningkatkan Hasil Belajar Siswa Sekolah Dasar. EDUKATIF: $\begin{array}{llll}\text { JURNAL ILMU PENDIDIKAN, } & \text { 865-870. }\end{array}$ https://doi.org/https://doi.org/10.31004/edukatif.v3i3.392

Suryadi, A., \& Berdiati, I. (2018). No TitleMenggagas Penelitian Tindakan Kelas Bagi Guru. PT. Remaja Rosdakarya.

Susanti, I. M. R. (2020). PENERAPAN MODEL PEMBELAJARAN KOOPERATIF TIPE STUDENT TEAM ACHIEVMENT DIVISION (STAD) UNTUK MENINGKATKAN HASIL BELAJAR IPA PADA SISWA KELAS VI SD NEGERI 4 KARANGASEM SEMESTER I TAHUN PELAJARAN 2017/2018. Jurnal Inovasi, 6(3), 42-51. http://www.jurnalinovasi.my.id

Susanti, Y., Wahjoedi, \& Utaya, S. (2017). Peningkatan Aktivitas Dan Hasil Belajar Melalui Pembelajaran Kooperatif Tipe Stad. Jurnal Pendidikan: Teori, Penelitian, dan Pengembangan, 2(5), 661-666. https://doi.org/http://dx.doi.org/10.17977/jptpp.v2i5.9160

Wijaya, H., \& Arismunandar, A. (2018). Pengembangan Model Pembelajaran Kooperatif Tipe STAD Berbasis Media Sosial. Jurnal Jaffray, 16(2), 175-196. https://doi.org/10.25278/jj71.v16i2.302 